will be too slow to be of any real use. Ian Shaw of the UK Department of Trade and Industry's Biotechnology Directorate emphasized the necessity of quicker action: "Although it is right to look at the fundamental journey for biotechnology to take over a ten-year period, there are practical and pragmatic measures that could be implemented within a shorter timescale to ensure that Europe does not fall behind [other countries].” Among DTI's suggestions are priority support for postgenomics research, and the development of an educational program to help EU citizens participate in debates about genetics in society.

Referring to GM crop approvals, the UK government called for "minimal science-based regulation of controversial activities" and said that "regulation will need to be based on sound science and should be proportionate, practicable and enforceable." And conscious that the UK hosts by far the strongest biotechnology sector in Europe, it, too, called for faster implementation of the European Patent Directive and for the fostering of a unitary European patent. In addition, it asked the EC to look for ways to remove the stigma attached to bankruptcy in European business, with the aim of encouraging risk-taking and investment in an industry that inevitably suffers a high level of product failures.

- Greenpeace repeated its usual demands for a ban on any release of GMOs into the environment.

Adoption of the new strategy is only the first step in the process, says Siebert. The document then has to be considered by various Councils of Ministers, and by the European Parliament, the Committee of Regions, and the Economic and Social Committee. And implementation of the strategy will be piecemeal, notes Siebert. The Commission itself will act on some of the points, such as genomics research funding and adoption of a community patent, while others, such as public education initiatives, will be left to member states and the private sector.

Peter Mitchell, London

\section{Genentech awarded critical antibody patent}

n December 2001, after a more than decade-long dispute over inventorship with Celltech R\&D Ltd (Slough, UK), the biotech giant Genentech (S. San Francisco, CA) was awarded a patent claiming broad rights to fundamental methods for the recombinant expression of antibodies. The patent covers one of the principal processes used in the manufacturing of lucrative therapeutic and diagnostic antibody drugs, such as Genentech's breast-cancer therapeutic Herceptin, and could potentially block the production of antibody products by rival companies or increase their royalty burden.

Genentech's US Patent No. 6,331,415 ("Cabilly patent"), which was awarded on December 18, is a continuation of a previously issued Cabilly patent filed by Genentech on April 8, 1983 as part of a collaborative effort between Genentech and the City of Hope National Medical Center (Duarte, CA). The newly issued patent has 36 claims for recombinant methods and vectors to produce immunoglobulin (Ig) molecules and functional Ig fragments in transformed host cells.

Genentech's application was on file with the US Patent and Trademark Office (PTO; Washington DC) when Celltech's US patent 4,816,397 ("Boss patent"), covering the same patentable invention, was granted in March 1989, having been filed on March 24, 1983. In February 1991, after the issuance of the Boss patent, Genentech asked the Board of Patent Appeals and Interferences to begin an interference action to determine which of the two companies had rights to the invention.

Seven years later in August 1998, a panel of administrative patent judges found in favor of Celltech, criticizing the evidentiary value of the Genentech inventor's notebooks and corroborating evidence. Genentech responded by filing suit in the US District Court of California, resulting in the March 2001 decision that the Celltech patent, although filed two weeks earlier than Genentech's application, did not have a priority position: US patent law, unlike other countries, gives priority to the person who is first to invent rather than first to file a patent application. The US District Court of California filed an order to simultaneously vacate the 1998 interference decision, revoke and withdraw Celltech's 1989 patent, and clear the way for the PTO to grant and eventually issue the continuation of the Cabilly patent to Genentech, granting the company rights to the technology until 2018, 17 years from the issue date. Celltech is appealing the decision.

A court-ordered settlement-required by the US District Court before it would render its decision on inventorship-provides Celltech with a license to the Genentech patent to continue its $R \& D$ activities in return for an undisclosed royalty on future product sales. Notably, Genentech will pay Celltech for any lost income it would have generated from licensing revenue or the sales of any products covered by the Boss patent, which would have expired in 2006.

Meanwhile, Genentech believes that issuance of the Cabilly patent could affect many companies. "The recently issued patent broadly covers the co-expression of immunoglobulin heavy and light chain genes in a single host cell," says Sean Johnston, Genentech's vice president of intellectual property. "We do not believe that the claims are limited by type of antibody (murine, humanized [ $90 \%$ human sequence], or human) or by host cell type."

Leading antibody companies such as IDEC (San Diego, CA), Abgenix (Freemont, CA), and Medarex (Princeton, $\mathrm{NJ}$ ) are now comparing their technologies with the issued patent claims to determine whether they need a license from, or should pay royalties on current products to, Genentech. And Celltech licenseessuch as ImClone Systems (New York), which is co-developing an anti-cancer drug with Bristol Myers Squibb-may now need to go to Genentech for a license. Some suggest that if licensing and royalty payments are owed, there will be a corresponding increase in the production costs of those therapeutic and diagnostic antibodies. But Genentech disagrees. "Any increased cost depends largely on the particular antibody, the technology used to produce the antibody, and how many of those steps need to be licensed," says Johnson.

Investors are also scrambling to determine whether companies will now need to pay unanticipated royalties. "This patent aroused our interest because there are 11 antibody-based drugs on the market and over 90 additional products under development at various biotechnology companies," says BancAmerica Securities (New York) biotechnology analyst Thomas McGahren. "We have reviewed this patent and consider it to be very important, and companies producing chimeric or humanized antibodies will have to review carefully and determine if they need a license," says McGahren. "From an investment perspective, we are interested whether companies, such as MedImmune, will need a license or pay royalties on this essentially basic genetic engineering technology because they produce humanized antibodies," he adds. "Medarex and Abgenics, which produce human antibodies, may not have to face additional royalty and licensing fees."

Debra Robertson, San Diego, CA 